\title{
The Impact of Using Multimedia Technologies on Students Academic Achievement in the Bakirköy Final College
}

\author{
Dr. Necdet Inceday ${ }^{*}$ \\ Bakırköy Final College \\ *Corresponding Author: Dr. Necdet Incedayı, Bakırköy Final College

\begin{abstract}
The aim of this page is to find out the impact of using animation on college level students' academic achievement in the Bakırköy Final College. 28 students were selected and it is divided into two equal groups. Modern technologies are used for first group and traditional approaches are preferring for second group. This study observed a significant relationship between students' use of animation technology and their achievements in geography course. This paper reports on the results of the exam, documenting what was revealed regarding how technology is used among students at the Final College, as well as the important benefits on their achievements during geography courses. Animation technologies usage might produce comparatively more significant increases in geographic academic achievement than would non usage.
\end{abstract}

Keywords: Education, Geography, Bakırköy Final Caollege, Modern Information Technologies, Multimedia, Animation, Achievement

\section{INTRODUCTION}

Effective teaching and learning is impossible nowadays without the use of various techniques based on modern ICTs and innovations of the so-called 'digital' pedagogy. Within a high-tech information educational environment, multimedia is one of the powerful tools that assists teachers to enhance their professional capacity and helps students to achieve their educational goals (Badarch, 2013: 4). Moreover, modern multimedia in combination with social media and open educational resources contribute to reaching one of the Bakırköy Final Schools main goals in education to make quality education more accessible for all.

The concept of multimedia is defined in many ways. Most of the definitions agree on the characteristic that multimedia contains texts, graphics, animations, video and sound in an integrated way and the content can be structured and presented differently. So multimedia represent the consolidation of all elements of technology as they combine sound, image, video, drawing \& text with a high quality in addition to the interactive environment (Fouda, 2008, p. 386). Multimedia technologies present reactive, proactive, and mutual interactions (RhodesandAzbell, 1985; cited in Schulmeister, 1997).

Multimedia can be viewed as a learning tool and a means of communication. Within learning situations, multimedia products and online services can be used creatively and reflectively. Furthermore, multimedia can be used to foster learning subject matters and cross-curricular.

Multimedia is very helpful and fruitful in education due to its characteristics of interactivity, flexibility, and the integration of different media that can support learning, take into account individual differences among learners and increase their motivation (Aloraini, 2005, p. 55-75).

The provision of interaction is the biggest advantage of the digital media in comparison with other media. It refers to the process of providing information and response. Interactivity allows control over the presented content to a certain extent: learners can change parameters, observe their results or respond to choice options. They can also control the speed of applications and the amount of repetition to meet their individual needs. Furthermore, the ability to provide feedback tailored to the needs of students distinguishes the interactive multimedia from any other media without a human presence. However, many aspects need to be taken into account when using multimedia in education (Andresen and Brink, 2013:23-26) 
Multimedia can appeal to many types of learning preferences - some students profit more from learning by reading, some by hearing and some by watching, etc. In addition, the use of multimedia allows for different ways of working - students can decide on their own how to explore the materials as well as how to use interactive and collaborative tools.

Moreover, students can adjust their own learning processes according to their abilities and preferences. They can work according to their interests, repeat material as much as they want reducing embarrassment concerning their learning outcomes. The use of multimedia can thus be tailored to the students' differences in interests, social and cultural backgrounds, learning preferences and rates, etc.

Individual learning can promote active, self-directed learning. In addition, multimedia applications can be used to facilitate group work. Small groups of students can work through multimedia applications together - in order to learn from each other as well as to improve their dialogue skills. (Andresen and Brink, 2013:25-26).

\section{OBJECTIVES}

This study was conducted to investigate the possible relationship between students' use of technology and their achievements in geography courses at Bakırköy Final College. The study will help us identify data regarding the way educators employ multimedia strategies in achieving the instructive activities in different subjects in the compulsory curricula and what the effects on the cognitive development of children. Especially in geography lessons such as plate tectonics, volcanic activities, natural hazardous the use of multimedia is more effective. Furthermore this article also aims to emphasize this feature as well.

\section{MeTHOdology}

This study was conducted on 40 students studying geography during their only one geography lesson about subject of plate tectonic. To this end, an experiment of two equivalent groups was designed, one of the groups is taking lesson as an modern (experimental) and the other is traditional (control); each of them consists of 20 students.

The lecture was given to the first group using an animation (Figure 1) which uses multimedia treated as an experimental group, while the second group was given the same lecture using the traditional method which uses the dialog and discussion technique treated as a control group.

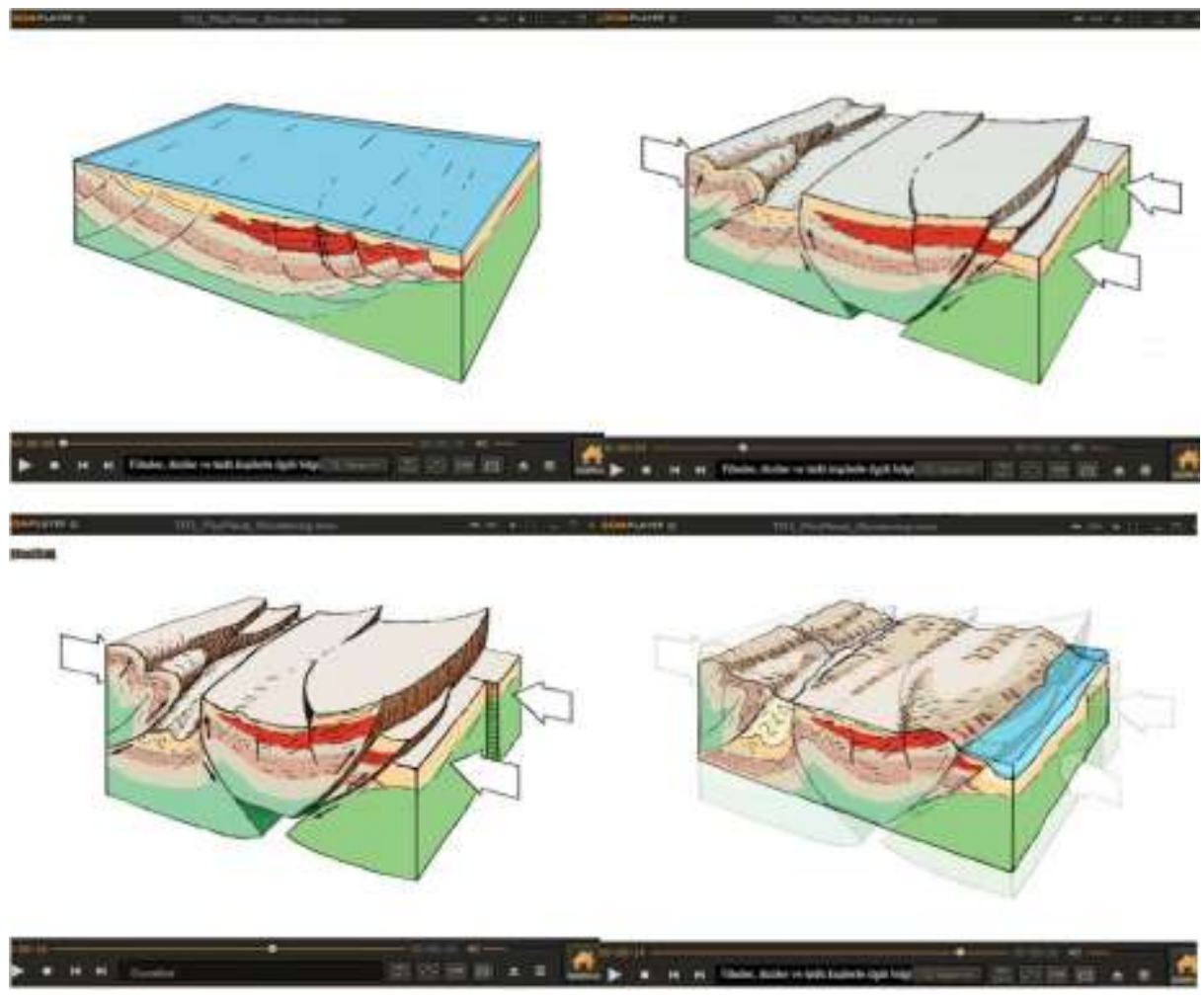

Figure1. Different images from the parts of the animation 
An exam (Figure 2) regarding understand of geography lesson was sent to the both of the student groups. Both groups were subjected to tests in the subject tackled by the lecture.

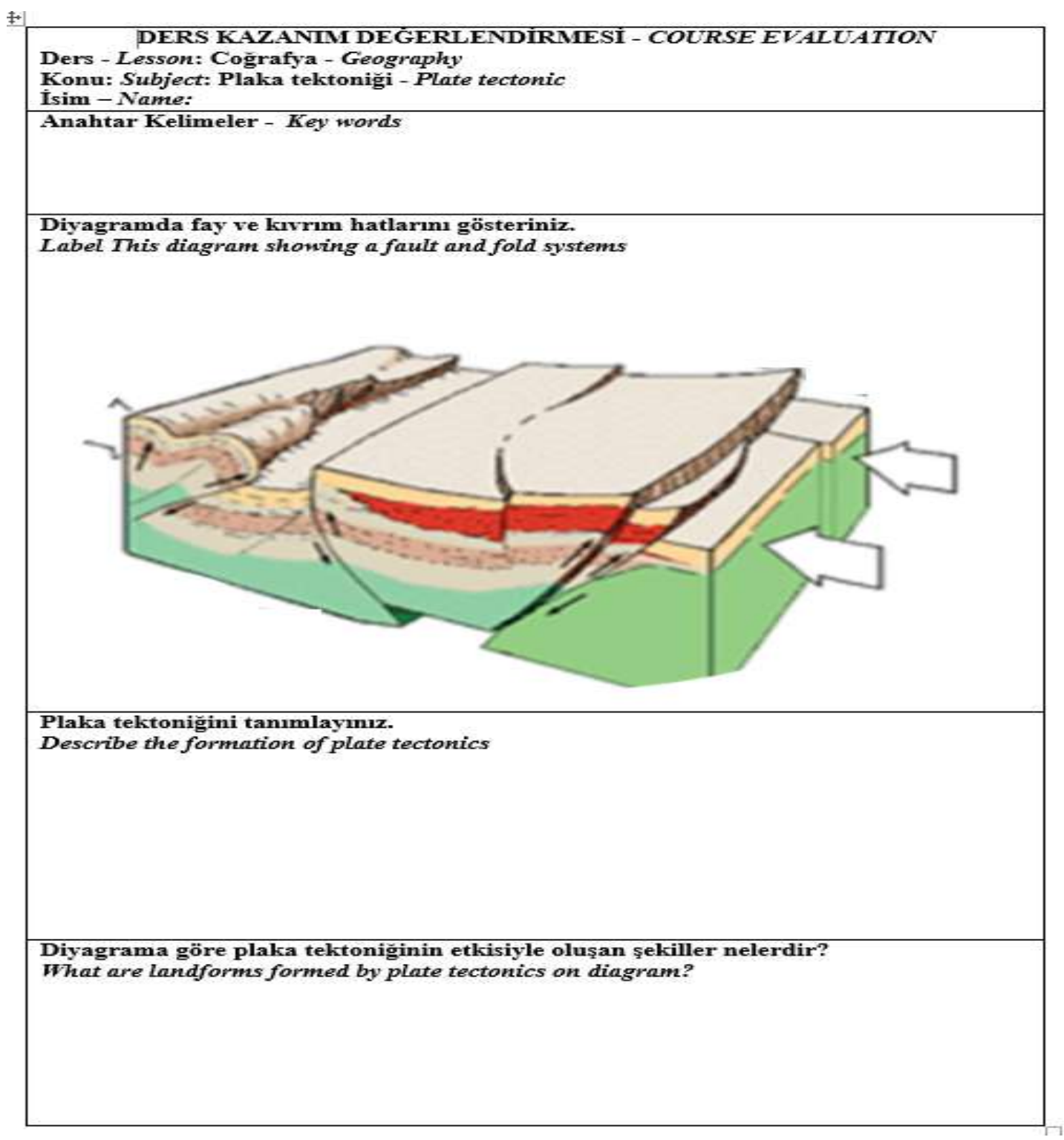

Figure2. Course Evaluation Form

The correlation coefficient and descriptive statistics were implemented to study the frequency of, and relationship between, multimedia technologies and learning achievement in Geography courses.

The researchers in the following statistical processing used the Statistical Package (SPSS) for analysing all processes:

- Calculating the median, the standard deviation and the variant, etc.

- F- Test, T-Test and Mann Whitney U test to examine the difference between the performance of control and experimental groups.

\section{ReSUlts}

After applying the experiment, the researcher conducted an academic achievement test then he analysed the study outcomes to figure out the impact of using multimedia on students' academic achievement and the results were as follows:

Meanwhile, the analysis result of the test showed the following: There are statistically-significant differences between the experimental group and the control group. (Figure 3, Table 1, Table 2). 
The Impact of Using Multimedia Technologies on Students Academic Achievement in the Bakirköy Final College

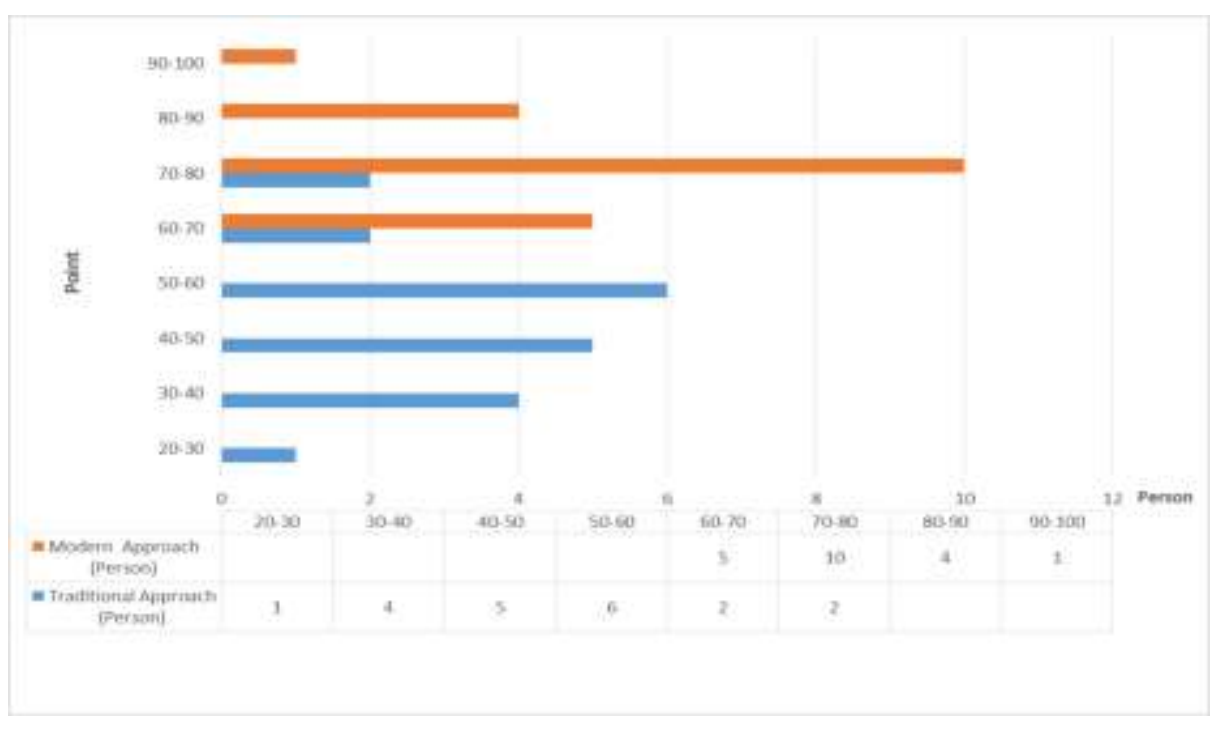

Figure3. Frequency results of the academic achievement test for the groups

Table 1 shows statistically significant differences between the control and experimental groups.

Table1. Frequencies of Numbers in the Sequence

\begin{tabular}{|c|c|c|c|c|c|c|}
\hline \multirow[t]{2}{*}{ Point } & \multicolumn{3}{|c|}{$\begin{array}{l}\text { TraditionalApproach } \\
\text { (Control Group) }\end{array}$} & \multicolumn{3}{|c|}{$\begin{array}{l}\text { Modern Approach } \\
\text { (Experimental Group) }\end{array}$} \\
\hline & Frequency & $\begin{array}{l}\text { Difference from } \\
\text { Average }\end{array}$ & $\begin{array}{l}\text { Average } \\
\text { Differences of } \\
\text { Numbers Squares }\end{array}$ & Frequency & $\begin{array}{|ll|}\text { Difference } & \text { from } \\
\text { Average } & \end{array}$ & $\begin{array}{l}\text { Average Differences } \\
\text { of Numbers Squares }\end{array}$ \\
\hline 20 & 1 & -25 & 625 & & & \\
\hline 30 & 4 & -15 & 225 & & & \\
\hline 40 & 5 & -5 & 25 & & & \\
\hline 50 & 6 & 5 & 25 & & & \\
\hline 60 & 2 & 15 & 225 & 5 & $-10,5$ & 110,25 \\
\hline 70 & 2 & 25 & 625 & 10 & $-0,5$ & 0,25 \\
\hline 80 & - & - & - & 4 & 9,5 & 90,25 \\
\hline 90 & - & - & - & 1 & 19,5 & 380,25 \\
\hline
\end{tabular}

The standard deviation, the median, the variant, $\mathrm{F}$ Test, and $\mathrm{T}$ Test were calculated for both the control and experimental groups in the academic achievement test as shown in Table 2.

Table2. Results of the academic achievement test for the groups.

\begin{tabular}{|l|l|l|}
\hline Groups & $\begin{array}{l}\text { Traditional } \\
\text { Approach }\end{array}$ & $\begin{array}{l}\text { Modern } \\
\text { Approach }\end{array}$ \\
\hline Number & 20 & 20 \\
\hline Mean - Median & 45 & 70,5 \\
\hline Lowest point & 20 & 60 \\
\hline Highest Point & 70 & 90 \\
\hline Standard Deviation & 13,57242 & 8,25578 \\
\hline Variant (Standard Deviation) & 184,21053 & 68,15789 \\
\hline Population (Standard Deviation) & 13,22876 & 8,04674 \\
\hline Variant (Standard Deviation of Population) & 175 & 64,75 \\
\hline Mode & 45 & 70,5 \\
\hline Mode frequency (Peak number of repetitions) & 45 & 10 \\
\hline Range & 6 & 30 \\
\hline Standard Error & 50 & 1,8460 \\
\hline The sum of the squares of the differences of the mean of the numbers & 3,034 & 1295 \\
\hline Coefficient of Change & 3500 & 11,710 \\
\hline Sum of numbers in the series & 30,16 & 1410 \\
\hline F-Test Value & 0,091168 & \\
\hline T-Test Value & 3,6653 & \\
\hline
\end{tabular}


The F-Test / ANOVA (Analysis of Variance) was used to test the hypotheses about the significance of the difference between the means of two or more groups of variance analysis. The above tables contain descriptive statistics and variance analysis values for our data. The Mean values in the Descriptive table indicate the average grades of the students. The mean values of the students prepared by the traditional method were low with (45); the average of those who learn the lesson with modern approach is higher (70.5).According to the $\mathrm{F}$ test result made at the $95 \%$ confidence level, $\mathrm{F}$ score $=0.091168<$ F-table $(19,19 ; 0.05)=2.11$. The significance level of the notes was found to be $p$ $<0.05$.If $\mathrm{p}<0.05$, the HA hypothesis is accepted. For this reason, the variances are not homogeneous for bipartite probability. So; the mean grades of both groups differ significantly.

In addition, by comparing the average of the two groups taking courses with traditional and modern methods, it was decided by the result of the Paired-Samples "T test" that the difference is coincidental or not statistically meaningful. The two unequal variances were calculated to be 3.6563 in two directions. $\mathrm{T}$ Account $=3.6653>\mathrm{T}$ Table $(\mathrm{FD}=20+20-2=38, \alpha / 2=0.025)=2.0121$

$\mathrm{P}<0.05$.In this case the difference between the two groups' mean is statistically significant.

The Mann-Whitney $U$ test was used for the significance test of the difference between the two means.

$$
\begin{aligned}
& \mathrm{U} 1=\mathrm{n} 1 . \mathrm{n} 2+((\mathrm{n} 1(\mathrm{n} 1+1) / 2))-\mathrm{R} 1=530.5 \\
& \mathrm{U} 2=\mathrm{n} 1 . \mathrm{n} 2-\mathrm{U} 1=-130.5 \\
& \mathrm{U}=\mathrm{Max}(\mathrm{U} 1, \mathrm{U} 2)=530.5 \\
& \alpha=0.05 .
\end{aligned}
$$

The table statistic is 238 with a 0.05 error level and (FD:19,19) degrees of freedom.

$$
\mathrm{U} \text { Account }=530.5>\mathrm{U} \text { Table }=238
$$

The Ho hypothesis is thus invalidated and proves that there are significant differences between the notes of the two groups.

After getting the statistical results of the academic achievement tests of the control and experimental groups, the positive impact of using multimedia was clear on geography teaching. Multimedia and its uses in geography education and on better scientific academic achievement of the experimental group compared to the results of the control group, which proves that using multimedia in education is an effective means of reaching a better learning.

\section{DISCUSSION}

According to the study results which indicated the effective use of multimedia compared to the traditional methods of teaching, the study recommends the following:

The dramatic growth of multimedia creates new opportunities for engaging college students. Multimedia techniques should be used judiciously in the learning process. Multimedia can be used to motivate discussions. The trends up updating and improving the teaching strategies subscribe to increasing the multimedia strategies of the teaching process, developing active-creative teaching, within the multitude of educational strategies, the issue that merges is of an efficient, contextual combination of formal and informal strategies, traditional and modern strategies, according to criteria of complementarity, compensation and mutual support. The use of multimedia by students needs to be supported by very skilled teachers. They must guide students through the learning process and provide them with appropriate and effective learning strategies. Like the use of textbooks, the use of educational multimedia fosters teaching strategies, where the teacher's role is not just that of information provider but the one of guide, supporter and facilitator.

\section{CONClusion}

Multimedia often requires more equipment to deliver a message than more traditional mediums. Whenever equipment is involved, there is the chance that the equipment will fail. Time is a precious commodity and you don't want to spend time with your customer, client or business associates trying to fix presentation equipment, change a light bulb, get a new computer or search a hard drive for a missing multimedia file. 
The quality of the multimedia is very important. Given that multimedia clips can vary greatly in quality, you may be sending the wrong message inadvertently. Throwing together a bunch of unrelated images or poorly recorded sounds can be annoying to those receiving your message. On the other hand, high-quality multimedia can be expensive to create or purchase.

Even with software making multimedia easier than ever to develop and incorporate into messages, it still takes time (smallbusiness.chron.com).

\section{ACKNOWLEDGMENTS}

I would like to thank Bakırköy Final School and its administrators for providing the survey and other studies in preparation of the page.

\section{REFERENCES}

[1] Albion, P. (1999). Heuristic evaluation of educational multimedia: From theory to practice. In Winn J. (Ed.), Proceedings of the 16th Annual Conference of the Australasian Society for Computers in Learning in Tertiary Education, Brisbane: Australasian Society for Computers in Learning in Tertiary Education, (pp 9-15).

[2] Abdul-Majid, A.S. (2002). The impact of a proposed program using multimedia enhanced computer in the teaching of analytic geometry on the achievement of knowledge and the development of thinking skills divergent and decision-making for students of first grade secondary South Valley University, College of Education, Sohag.

[3] Abu Nadar, A. (2003). The effectiveness of using a computer program in the development of some basic skills needed to operate the video camera technology among students in education, unpublished Master Thesis, Institute of Educational Studies and Research, Cairo (2003)

[4] Abu Yunis, A. (2005). The effectiveness of multimedia software for teaching engineering in the second row preparatory, unpublished Ph.D. thesis, University of Damascus, Damascus.

[5] Alfar, İ. (2009). Preparation and production of interactive multimedia software (second edition), Delta Computer Technology, Tanta, Egypt.

[6] Algerioy, A. M. (1999). The impact of multimedia on the collection of first-grade students in secondary mathematics in Riyadh, unpublished Master Thesis, King Saud University.

[7] Allen, D., (1998). The effect of computer - based multimedia lecture presentation on comment college microbiology students achievement, attitudes and retention D.A.I., August, 448-A.

[8] Anderson, Lorin W.; Krathwohl, David R., eds. (2001). A taxonomy for learning, teaching, and assessing: A revision of Bloom's taxonomy of educational objectives. Allyn and Bacon.

[9] Andresen, B. B., Brink, K. (2013). Multimedia in education: Curriculum. UNESCO Institute for Information Technologies in Education, Moscow,

[10] Beichner, R.J. (1994). Multimedia Editing to Promote Science Learning, Journal of Computers in Mathematics and Science Teaching (3) (1994), pp. 55-70

[11] Callaway, J. A. (1997). An interactive multimedia computer package on photosynthesis for hi school students based on matrix of cognitive and learning styles. D.A.I-A 57/07, P2951.

[12] Carlson, S. (2002).The missing Link in Educational Technology: trained teachers. International Journal of Technologies for the Advancement of Knowledge and Learning, 4(4), 7-11.

[13] CEO Forum on Education and Technology. (1999). Professional development: A link to better learning. The CEO Forum school technology and readiness report-year two. Washington, DC: Author.

[14] Darling-Hammond, L., \&Bransford, J. (2005). Preparing teachers for a changing world: What teachers should learn and be able to do. San Francisco, CA: Jossey-Bass.

[15] Draper, S. (1996). Observing, measuring, or evaluating courseware: A conceptual introduction. Retrieved May 12, 2015, from http://www.icbl.hw.ac.uk/ltdi/implementing-it/measure.pdf.

[16] Ekinci, D., CoğrafyaEğitimindeHaritalar, 21. YüzyıldaDeğişenYaklaşımlarve YükseköğretimdeCoğrafya Eğitimi (Ed. RamazanÖzey), PegemAkademi, 75-96, İstanbul, 2013.

[17] Ekinci, D., CoğrafyaÖğretimindeGörselTeknolojiler, CoğrafyaEğitimindeKavramveDeğişimler, (Ed. Özey, R.,), Pegem Akademi,243-262, İstanbul, 2010. 
[18] Ekinci, D., Ekinci, B., Geographic Information Systems (GIS), Remote Sensing (RS) Technologies and theirs applications into life, International Scientific Conference "High Technology in Educational System Advancement and Current Trends in Teaching Methodology", pp.192-193, 13-14 November 2008, Aşgabat, Türkmenistan.

[19] Ekinci, D., Karakoç, E., Hut, D., Avcı, H.E.; Using Multimedia Technologies as a Current Trends on Social Sciences Education,pp. 93-106, First International Symposium on Sustainable Development (ISSD’09,) June 9-10, 2009 Sarajevo, Bosnia and Herzegovina.

[20] Ekinci, D., Özşahin, E., “Geovisualization: A Tool for Teaching Geomorphology”, 21st International Teaching and Learning Conference, 19-23 April, 2010, Florida State College at Jacksonville, USA.

[21] Ekinci, D., Teaching and Strategy Approach on Geography Education in Universities, International Scientific Conference "High Technology in Educational System Advancement and Current Trends in Teaching Methodology”, pp.209, 13-14 November 2008, Aşgabat, Türkmenistan.

[22] Ghazzawi, M. (2002). Design software learning computerized study of their impact and the impact of variable movement in the collection of sixth grade students the basic concepts of pilgrimage for some, Journal of Educational and Psychological Sciences, Volume III, Issue IV, Bahrain.

[23] Glenn, A.D. (1997).Technology and the continuing education of classroom teachers. Peabody Journal of Education, 72(1), 122-128.

[24] Hadmin, D., (2000). The world of Multimedia, http://vml.hqadmin.doe.govAQMULTI.html.

[25] http://smallbusiness.chron.com/disadvantages-using-multimedia-professional-communication-18491.html

[26] https://serc.carleton.edu/sp/library/media/index.html

[27] Ibrahim, W.M. (2003). The effectiveness of multimedia in teaching basic computer to collect and the survival of the impact of learning of students at the College of Education Quality. Master, Egypt.

[28] Kennedy, D. M. and C. McNaught. (1997). Design elements for interactive multimedia. Australian Journal of Educational Technology, 13(1), 1-22.

[29] Mayer, R. E. (2001). Multimedia learning, Cambridge: Cambridge University Press, ch. 1, pp. 2-3.

[30] Means, B., Blando, J., Olson, K., Middleton, T., Morocco, C., Remz, A., \&Zorfass, J. (1993). Using technology to support education reform. Washington, DC: U.S. Department of Education. Retrieved May 16, 2014, from http://www.ed.gov/pubs/EdReformStudies/TechReforms/.

[31] Nasr, H. A. (2005). Study of effectiveness of the use of multimedia technology in the teaching of computer engineering at the third preparatory grade pupil achievement and the development of creative thinking they have, Cairo University.

[32] Obaid, J. (2001). A program using the bags for the development of multimedia skills necessary to prompt the resident high school mathematics, unpublished Ph.D. thesis, Institute of Educational Studies and Research, Cairo.

[33] Pashler, H., Mcdaniel, M., Rohrer, D., \& Bjork, R. (2008). Learning Styles: Concepts and Evidence. Psychological Science in the Public Interest, 9(3), 105-119. Retrieved May 10, 2015, from http://steinhardtapps.es.its.nyu.edu/create/courses/2174/reading

[34] Riley, F., \& University of Hull. (1995). Understanding IT: Developing multimedia courseware. Hull: University of Hull

[35] Sethi. (2005). Multimedia Education: Theory and Practice. Mittal Publications, Ch. 1, pp. 1-8.

[36] Taylor, J., T. Sumner and A. Law. (1997). Talking about multimedia: A layered design framework. Journal of Educational Media, 23(2/3), 215-241.

[37] Trotter, A. (1999). Preparing Teachers for the Digital Age. Education Week Technology Counts 1999: 19(4): 37- 43.

[38] Tudor, S.L (2013). The Role of Multimedia Strategies in Educational Process. Procedia - Social and Behavioral Sciences 78, $682-686$

[39] Vaughan, T. (2011). Multimedia: Making It Works. 8th Edition. New York: McGraw Hill, 2011

[40] Yamauchi, L.G. (2008). "Effects of multimedia instructional material on students' learning and their perceptions of the instruction" (2008). Retrospective Theses and Dissertations. 15324. http://lib.dr. iastate.edu/rtd/15324 


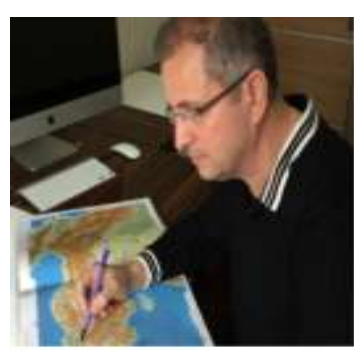

Dr. İnceday1, finished his primary and secondary in science is Sinop. On 1991, he graduated from İstanbul University Geography Department. He graduated from Marmara University, Institute of Middle East and Islam Countries as Master Degree. İnceday1 has doctorate degree thesis titled "The Ecological Evaluation of Kocasu River Delta and its Surroundings" İstanbul University Social Sciences Institute Geography Division in 2015. Furthermore, he worked as a Geography Teacher for 28 years. Dr. İnceday1 is a member of Bakırköy Final College. Research areas are eco-geography, disaster management, and geography education. He also special expert Bursa Province's geographical properties. Nowadays, İnceday1 is a researcher and he writes articles which titled about environment and geography education.

Citation: Dr. Necdet Incedayl,. "The Impact of Using Multimedia Technologies on Students Academic Achievement in the Bakirköy Final College" International Journal of Humanities Social Sciences and Education (IJHSSE), vol 5, no. 1, 2018, pp. 40-47. doi: http://dx.doi.org/10.20431/2349-0381.0501007.

Copyright: (ㅇ 2018 Authors. This is an open-access article distributed under the terms of the Creative Commons Attribution License, which permits unrestricted use, distribution, and reproduction in any medium, provided the original author and source are credited. 